\title{
Сулейменова Г.А.
}

\section{Технология подготовки будущего учителя начальных классов к проведению уроков чтения}

\author{
Suleimenova G.A. \\ The technology of training future elementary \\ school teachers to teach reading
}

В данной статье автором представлена технология подготовки будущего учителя начальных классов к проведению уроков литературного чтения. Рассмотрена система приемов развития критического мышления для обучения младших школьников на уроках литературного чтения

Ключевые слова: технология, чтение, критическое мышление, обучение

Сулейменова Гульмира Амангалиевна Магистр, преподаватель Инновационный Евразийский университет Казахстан, г. Павлодар, ул. Ломова, 45

\begin{abstract}
In this article the author presents a model of communicative competence of future teachers in lessons of Russian language as the basis of forming the patriotic language and the stages of identity formation
\end{abstract}

Key words: technology, reading, critical thinking, teaching

\author{
Suleimenova Gulmira Amangalievna \\ Master, Teacher \\ Innovative Eurasia university \\ Kazakhstan, Pavlodar, Lomov st., 45
}

Современная начальная школа на современном этапе продолжает своё активное развитие. Основной целью модернизации всей системы казахстанского образования в последние десятилетие является - повышение качества образования. Начальная школа должна отвечать актуальным и перспективным потребностям личности, общества и государства. Запрос государства к системе образования заключается в необходимости повышения «качества образования». Этот запрос на современном этапе имеет и новое содержание [1, с.8].

В условиях современного образования возникает необходимость в изменении сущности, типа образовательного процесса. Это связано с тем, что для учащихся становится все более актуальным не просто процесс научения, не только знания, а учение и самообразование, при котором знания и умения становятся средствами развития и саморазвития личности.

Поэтому, опыт работы учителей показывает, что все концепции обучения младших школьников так или иначе ориентированы на развитие мышления, способностей, познавательных интересов и т.д. 
Анализ психолого-педагогической литературы показал, что учителями используются разные технологии обучения, в нашем случае для проведения уроков литературного чтения, такие как:

- развивающее обучение (Д.Б. Эльконина, В.В. Давыдова и др.);

- гуманная педагогика (Ш. Амонашвили и др.);

- личностно-ориентированное (И.С. Якиманская и др.);

- коллективное взаимообучение (А.Г. Ривин и др.);

- интенсивное обучение грамоте (Н.А. Зайцев и др.);

- развития критического мышления (основателями были американские ученые Чарльз Темпл, Джинни Стил и российские педагоги- исследователи С.И. Заир-Бек, И.В.Муштавинская и др.).

Мы остановились на технологии развития критического мышления, как актуальной для проведения уроков литературного чтения, позволяющей добиться позитивных результатов в формировании мыслительной деятельности младших школьников.

Данная технология состоит в развитии мыслительных навыков учащихся, необходимых не только в учебной деятельности, но и в дальнейшей жизни (умение принимать решения, работать с информацией, анализировать различные стороны явлений); реализации компетентностного подхода в обучении и воспитании младших школьников.

Особенностью данной педагогической технологии является то, что ученик в процессе обучения сам конструирует этот процесс, исходя из реальных и конкретных целей, сам отслеживает направления своего развития, сам определяет конечный результат [2, с.41].

В условиях развития критического мышления, мы строим урок литературного чтения во вторых классах на основе взаимодействия трех этапов:

1 этап - «Вызов» (мотивационный компонент);

2 этап - «Осмысление» (содержательный компонент);

3 этап - «Рефлексия» (рефлексивный компонент).

Реализация данных этапов предполагает использование определенных приемов развития критического мышления на уроках литературного чтения. Исходя из результатов констатирующего эксперимента, мы использовали систему приемов развития критического мышления для обучения младших школьников 8-9 лет на уроках чтения:

- синквейны;

- чтение - суммирование в парах;

- чтение с остановками;

- логическая цепочка;

- уголки;

- кластер.

Рассмотрим более подробно данные приемы развития критического мышления, которые использовались нами в процессе проведения уроков литературного чтения во вторых классах.

1. «Синквейн» - это особое стихотворение, которое возникает в результате анализа и синтеза информации. Мысль, переведенная в образ, как раз и сви- 
детельствует об уровне понимания ученика. Этот прием, позволяет развивать способности резюмировать информацию, излагать сложные идеи, чувства и представления в нескольких словах, требует вдумчивой рефлексии. Это быстрый, но мощный инструмент для рефлексии.

2. «Чтение - суммирование в парах» можно использовать как для объяснения нового материала, так и для закрепления изученного. Смысл данного приема заключается, в том, что ученикам учитель предлагает несколько разных текстов по теме, или один и тот же текст нескольким парам учеников. Каждая группа изучает свой текст, на большом листе фиксирует его краткое содержание (выдержками из текста), затем перед всем классом воспроизводит содержание текста с опорой на свои пометки [3, с.14].

3. «Чтение с остановками». В начале урока учитель использует заранее подготовленный текст, затем ученики по названию текста определяют, о чем пойдет речь. На основной части урока текст учителем читается по частям, после прочтения каждого фрагмента ученики высказывают свои предположения о дальнейшем развитии сюжета.

Учителю необходимо найти в тексте оптимальные места для остановки. Данный вид работы способствует выработке у учащихся внимательного отношения к точке зрения друг друга. Умение слушать, аргументировать факты и доказывать свою точку зрения.

4. «Логическая цепочка». На уроке учителем зачитывается текс, после прослушивания ученикам необходимо построить события в логической последовательности. Данный прием помогает ученикам при пересказе текстов.

5. «Уголки» - можно использовать на уроках литературного чтения при составлении характеристики одного из героев какого-либо произведения. Класс делится на две группы. Одна группа готовит доказательства, используя текст и свой жизненный опыт, положительных качеств героя, другая - об отрицательных, подкрепляя свой ответ выдержками из текста. Данный прием используется после чтения всего произведения. В конце урока делается совместный вывод. Такой прием учит детей диалогу, культуре общения.

6. «Кластер» суть данного приема заключается в выделении смысловых единиц текста и графическом их оформлении в определенном порядке в виде грозди. Использовать этот прием можно на всех этапах проведения урока. При выполнении кластера необходимо соблюдать следующие правила: выделяем центр (тема), от нее лучи (крупные смысловые единицы), от них еще лучи (термины, понятия). Прием « кластер» помогает ученикам получить больший объем информации, чем при обычной работе по изучению темы. Хотелось бы отметить, что данный прием ученики используют с большим удовольствием при выполнении домашнего задания [4, с.21].

Таким образом, данные приемы в системном использовании на уроках литературного чтения позволяют получить, так как используются различные текстовые материалы, разные виды фиксирования информации, что позволяет оживить урок, сделать его увлекательным и эмоциональным. 


\section{Список используемых источников:}

1. Концепция развития системы образования Республики Казахстан до 2015 года // Учитель Казахстана. 2004. №18. С. 2.

2. Генике Е.А., Трифонова Е.А. Развитие критического мышления (Базовая модель). М., 2002. 35 с.

3. Равилова А.Ш. Развитие критического мышления младших школьников на уроках литературного чтения // Начальная школа. 2010. №7. С. 46-52.

4. Львов М.Р. Методика развития речи младших школьников. М., 1985. 476 с.

(C) 2015, Сулейменова Г.А.

Технология подготовки будущего учителя начальных классов к проведению уроков чтения
(C) 2015, Suleimenova G.A.

The technology of training future elementary school teachers to teach reading 